\title{
Cytogenetic Studies in Psilanthus ebracteolatus Hiern., a Wild Diploid Coffee Species
}

\author{
Ricardo A. Lombello and Cecília A. F. Pinto-Maglio* \\ Instituto Agronômico de Campinas, CxP. 028, Campinas 13001-970, SP, Brazil \\ Received September 17, 2003; accepted October 3, 2003
}

\begin{abstract}
Summary The genus Psilanthus is taxonomically close related to Coffea and its cytogenetic presents few studies due to the symmetry of its small chromosomes. In this work we analyzed cytogenetic features of Psilanthus ebracteolatus, a wild diploid coffee native from Ivory Coast included in the Coffee Germplasm Bank of the Instituto Agronômico de Campinas, Brazil. For heterochromatic banding assays the fluorochromes $\mathrm{CMA}_{3}$ and DAPI were used. For FISH assays the rDNA probes pTa71 and pScT7 were used. This species presented no DAPI positive bands, two $\mathrm{CMA}_{3}$ positive band pairs and one pair of NOR and one of 5S rDNA sites. Although we observed cytological similarity between the studied species and the few data presented for Psilanthus in literature, the analysis based on cytogenetic markers contributes to karyological characterization of this genus.
\end{abstract}

Key words FISH, NOR, Psilanthus, rDNA site.

The genera Psilanthus Hook.f. and Coffea L. constitute the tribe Coffeeae, which belongs to family Rubiaceae, subfamily Cinchonoideae (Wrigley 1988). These 2 close related genera are distinguished on the features of flower and flowering characteristics (Bridson 1987). While Psilanthus presents a long corolla tube associated with inserted anthers and a short style, Coffea presents a short corolla tube associated with exserted anthers and a long style (Couturon et al. 1998).

The genus Psilanthus presents about 30 species distributed in Africa, Asia and New Guinea (Charrier and Berthaud 1985, Bridson 1987). Although the species of this genus presents no commercial use and apparently little breeding potential (Wrigley 1988), the study of the cytogenetic characteristics of its species may provide new useful data to understand the karyotype evolution occurred in the subfamily Cinchonoideae.

Cytogenetic studies in Psilanthus and Coffea were limited by the relatively small size of their chromosomes $(1-3 \mu \mathrm{m})$ and the symmetrical karyomorphology observed in the studied species of these genera (Charrier and Berthaud 1985, Lombello and Pinto-Maglio 2003). There are few cytomolecular studies for Psilanthus and Coffea. In fact the cytological literature brings for Psilanthus basically chromosomal number reports of some representative species. Recently our research group presented cytogenetic data for 2 species of Psilanthus: $P$. bengalensis and $P$. travancorensis (Lombello and Pinto-Maglio 2003). Due to its economic importance Coffea has chromosome number accountings for most species of the genus, a few data of banding techniques, as those presented by Pierozzi et al. (1999), and more recently some cytomolecular information (Pinto-Maglio et al. 2000, Barbosa et al. 2001, Lombello and Pinto-Maglio 2002, 2003). For Psilanthus the chromosome number accountings present $2 n=2 x=22$ for all the studied species (Charrier and Berthaud 1985, Lombello and Pinto-Maglio 2003). All the studied species of both genera presented symmetrical karyomorphology. In such cases staining techniques with the fluorochromes DAPI and $\mathrm{CMA}_{3}$, that evidence heterochromatic regions rich in AT and GC bases respectively, are often used in order to characterize the species cytogenetically (Gupta et al. 1990, Yen-Yu et al. 2001). Fluorescent in situ hybridization (FISH) assays with rDNA probes are also an important tool for karyotype charac-

\footnotetext{
* Corresponding author, e-mail: maglio@iac.sp.gov.br
} 
terization (Heslop-Harrison 1991, Raina et al. 2001).

In the present paper we bring cytogenetic data for Psilanthus ebracteolatus Hiern, a wild diploid species that belong to the Coffee Germplasm Bank of Instituto Agronômico de Campinas (IAC). This species is originated from Ivory Coast, at humid and semidry forest of low altitude (Couturon et al. 1998). There are no previous cytomolecular data for this species. This study is part of a project that intends to characterize cytogenetically all the coffee species of this germplasm bank.

\section{Materials and methods}

\section{Plant material and slide preparations}

Seeds of Psilanthus ebracteolatus were collected at Coffee Germplasm Bank of the Instituto Agronômico de Campinas (IAC) in Southeastern Brazil. These seeds were germinated in Petri dishes. The root tips were excised and pre-treated with the anti-mitotic agent PDB ( $p$-dichlorobenzene) in satured solution at $16^{\circ} \mathrm{C}$ for $2 \mathrm{~h}$ and $30 \mathrm{~min}$. The material was fixed in Carnoy's solution (alcohol $3: 1$ acetic acid, v/v) for $24 \mathrm{~h}$ and stored at $-20^{\circ} \mathrm{C}$. For the slide preparation root tips were digested in a solution of citrate buffer with $2 \%$ of cellulase and $20 \%$ of liquid pectinase for $1 \mathrm{~h}$ at $37^{\circ} \mathrm{C}$ and squashed in $45 \%$ acetic acid.

\section{Fluorochrome staining and in situ hybridization}

For DAPI (4',6-diamino-2-phenylindole) and $\mathrm{CMA}_{3}$ (chromomicin) banding we followed the protocols of Schweizer (1976). In the hybridization we followed the protocol of Pendas et al. (1993). The probes used were pTa71, which contains one unit of 18S-5.8S-26S rDNA (9 kb) derived from common wheat (Gerlack and Bedbrook 1979), and pScT7, containing an insert of 5S rDNA with $300-500 \mathrm{pb}$ isolated from Secalle cereale. The probe pTa71 were labeled with biotin16-dUTP and pScT7 with digoxigenin-11-dUTP (Boerhinger Mannheim) by nick translation, following the manufacturer's instructions. The hybridized sites were detected with Avidin-Rhodamine for biotinilated probe pTa71 and IgG-FITC for digoxigenin labeled probe pScT7. The slides were counterstained with DAPI as showed by Heslop-Harrison et al. (1991) and mounted with anti-fading Vectashield (Vector Laboratories). Slides were examined with an Olympus BX50 epifluorescent microscope. Chromosome images were captured by an Optronics DEI-750 camera and processed in Image-Pro Plus 3.0 program only using contrast and lightning adjustments, functions that affect the whole image equally.

\section{Results and discussion}

The diploid chromosome number observed for Psilanthus ebracteolatus was $2 n=22$ and the karyomorphology observed was regular and symmetrical. The DAPI staining did not evidence positive AT rich bands (Fig. 1a). The $\mathrm{CMA}_{3}$ staining evidenced 2 band pairs located at terminal position in chromosomes. One pair presents stronger signal than the other (Fig. 1b). The hybridization with pTa71 probe evidenced one pair of 18S-5.8S-26S sites of rDNA (Fig. 1c) and the hybridization with pScT7 probe evidenced one pair of signals related to 5S rDNA (Fig. 1d).

The chromsome number observed $P$. ebracteolatus agrees with the numbers presented in literature for the genus Psilanthus (Mangenot and Mangenot 1958, 1962, Couturon et al. 1998). The karyomorphology regular and symmetrical reinforces the trend observed for the genus by Bouharmont $(1959,1963)$.

The absence of DAPI positive AT rich bands agrees with the results presented by Lombello and Pinto-Maglio (2003) for Psilanthus bengalensis and P. travancorensis. In coffee group at this time only Coffea humilis presented positive DAPI bands (Lombello and Pinto-Maglio 2003), what 


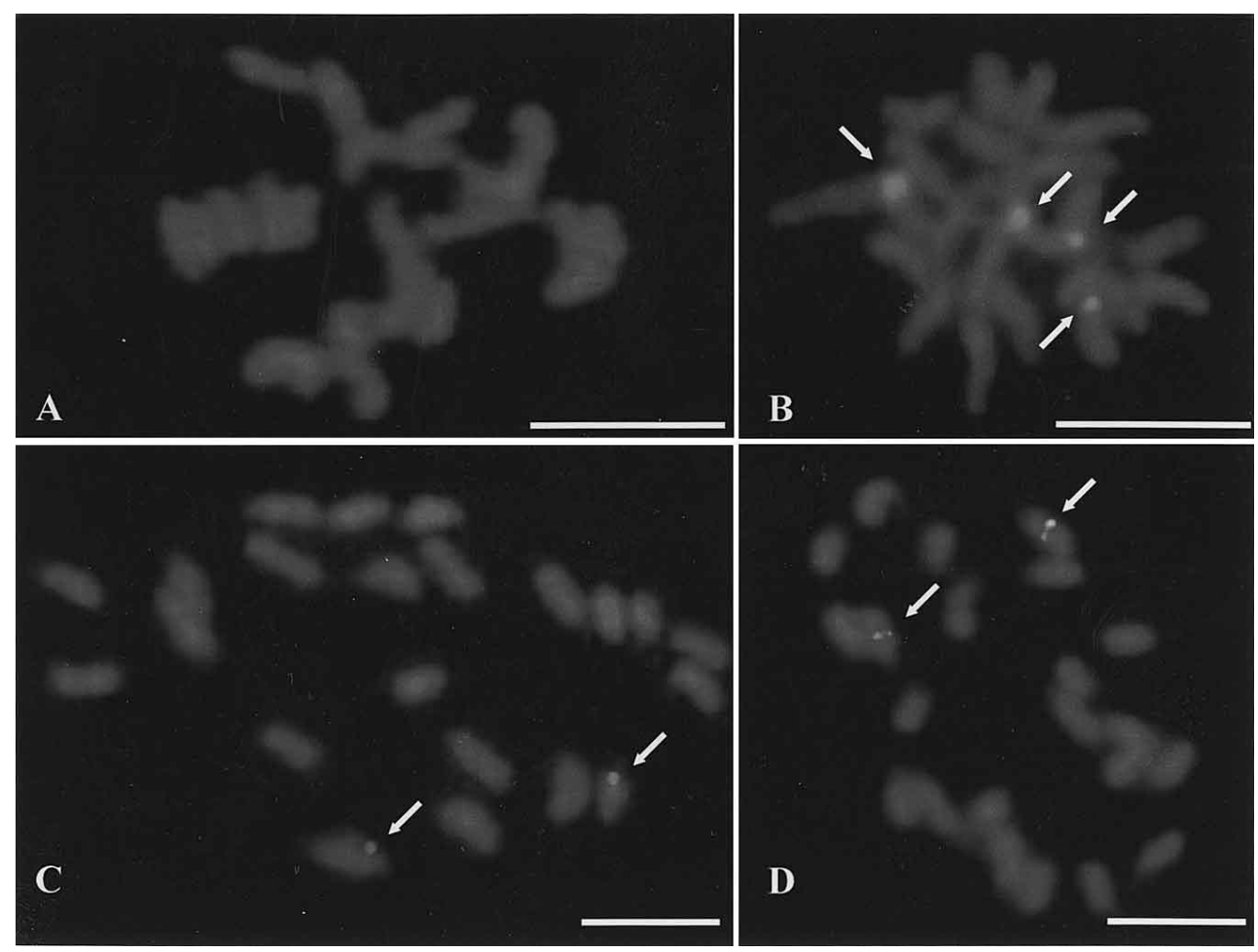

Fig. 1. Mitotic cells of Psilanthus ebracteolatus $(2 n=22)$. A) Stained with DAPI, B) stained with CMA, with arrows showing terminal CMA positive bands, C) stained with rodamine and counter-stained with DAPI, with arrows showing sites of $45 \mathrm{~S}$ rDNA, D) stained with FITC and counter-stained with DAPI, with arrows showing sites of $5 \mathrm{~S}$ rDNA. Bar $=5 \mu \mathrm{m}$.

seems to be an exception in this group. Pinto-Maglio et al. (2000) studying C. arabica, Barbosa et al. (2001) studying C. canephora, C. dewevrei and C. eugenioides and Lombello and Pinto-Maglio (2002, 2003) studying C. brevipes, C. kapakata, C. sp. Moloundou, C. racemosa, C. salvatrix, $C$. sessiliflora, Psilanthus bengalensis and P. travancorensis observed a uniform DAPI staining with no chromosomal bands.

The number of $\mathrm{CMA}_{3}$ positive bands observed here for P. ebracteolatus was the same of that observed in our earlier study (Lombello and Pinto-Maglio 2003) for P. travancorensis, although these bands present different features. In P. travancorensis there is one pair of terminal and one pair of intercalary signals, with the terminal sites presenting stronger signals than the intercalary ones (Lombello and Pinto-Maglio 2003) instead 2 pairs of terminal sites in P. ebracteolatus. In P. bengalensis only one pair of $\mathrm{CMA}_{3}$ positive bands were observed in terminal chromosome regions (Lombello and Pinto-Maglio 2003).

The number of 45S rDNA sites evidenced by FISH with pTa71 probe observed for P. ebracteolatus is the same of the other 2 species with cytological data. The features of these sites are similar between these species, with a strong terminal signal observed. The number and the features of the 5S rDNA sites evidenced by FISH with pScT7 probe is the same between the 3 Psilanthus studied species. The signals are located in intercalary regions of the chromosomes and are weaker than those observed for $45 \mathrm{~S}$ rDNA. The $45 \mathrm{~S}$ rDNA signal observed for $P$. ebracteolatus in FISH assay may refer to the strongest terminal signal observed in $\mathrm{CMA}_{3}$ staining. The $5 \mathrm{~S}$ rDNA signal observed cannot refer to the other $\mathrm{CMA}_{3}$ band, due to its intercalary position.

This low numerical rDNA site variation between coffee species was expected based on the lit- 
tle genetic polymorphism observed in this group, as showed by Lashermes et al. (1996) in their study with restriction fragment length polymorphism (RFLP) of chloroplast DNA in 25 taxa of coffee species. Cytogenetic studies seem to confirm this trend for coffee species (Barbosa et al. 2001, Lombello and Pinto-Maglio 2002, 2003). Moreover low numerical rDNA site variation no remarkable divergence in length signal was observed in FISH assays between $P$. ebracteolatus and the other two studied species $P$. bengalensis and $P$. travancorensis.

Lashermes et al. (1997) analyzed the phylogenetic relationships of some coffee-trees species based on variation of the sequences of the internal transcribed spacer (ITS) region of nuclear ribosomal DNA. With these data the authors organized coffee species in groups with similarity for these sequences. These groups present strong correspondence with geographical distribution. That work places $P$. ebracteolatus in a sister group to a clade consisting of East-African Coffea species as Coffea racemosa and C. sessiliflora, despite its West-African origin, and distant from P. travancorensis, placed in Madagascar group. This incongruence may be explained by the occurrence of introgressive hybridization between species of these clades, as pointed out by Cros et al. (1998) that analyzed the variation in chloroplast DNA between 23 taxa of coffee and observed several inconsistencies among West-African taxa. The cytogenetic data reinforces the arrangement of coffee species in biogeographical clades as proposed by Lashermes et al. (1997) and Cros et al. (1998).

Even though the studied species of Psilanthus present none numerical nor morphological rDNA site variation, the features of $\mathrm{CMA}_{3}$ bands of $P$. ebracteolatus are similar to those presented for C. sessiliflora (Lombello and Pinto-Maglio 2002) and C. racemosa (Lombello and Pinto-Maglio 2003), 2 species of its sister clade (Lashermes et al. 1997), and different of those presented for $P$. travancorensis (Lombello and Pinto-Maglio 2003), which is one terminal and one intercalary pair of $\mathrm{CMA}_{3}$ positive bands (Lombello and Pinto-Maglio 2003). The present data also agree with the results presented by Combes et al. (2000), that studied the polymorphism of microsatellite sequences in 13 coffee taxa and observed close genetic relation between species of Psilanthus and Coffea. These results reinforce the importance of chromosome mapping using cytogenetic techniques like fluorochromes banding and in situ hybridization, in studies that intend to compare related taxa with similar karyological characteristics.

\section{Acknowledgements}

We are grateful to Dr. Juan Orellana of Universidad Politécnica de Madrid, Spain, for rDNA probes supply and to Dr. Luiz Carlos Fazuoli and Masako Braghini of Centro de Análise e Pesquisa Tecnológica do Agronegócio de Café-IAC, Brazil, for the coffee seeds supply. This work was partially financed by Consórcio Brasileiro de Pesquisas Cafeeiras. We also thank FAPESP for fellowship.

\section{References}

Barbosa, R. L., Pierozzi, N. I., Lombello, R. A., Silvarolla, M. B. and Pinto-Maglio, C. A. 2001. Caracterização citomolecular de três espécies de Coffea L.: C. eugenioides, C. canephora e C. dewevrei. II. Simpósio de Pesquisa dos Cafés do Brasil, pp. 293-298.

Bouharmont, J. 1959. Recherches sur les affinités chromosomiques dans le genre Coffea. Bruxeles, Institut Nationale pour l'etude agronomique du Congo Belge 77, p. 94.

— 1963. Somatic chromosomes of some Coffea species. Euphytica 12: 254-527.

Bridson, D. 1987. Nomenclatural notes on Psilanthus, including Coffea sect. Paracoffea (Rubiaceae tribe Coffeeae). Kew Bull. 42: 817-859.

Charrier, A. and Berthaud, J. 1985. Botanical Classification of Coffee. In: Clifford, M. N. and Wilson, K. C. (eds.). Coffee: Botany, Biochemistry and Production of Beans and Beverage. Croom Helm, London, U.K. pp. 13-47.

Combes, M. C., Andrzeijewski, S., Anthony, F., Bertrand, B., Rovelli, P., Graziosi, G. and Lashermes, P. 2000. Characterization of microsatellite loci in Coffea arabica and related coffee species. Mol. Ecol. 9: 1178-1180. 
Couturon, E., Lashermes, P. and Charrier, A. 1998. First intergeneric hybrids (Psilanthus ebracteolatus Hiern $\times$ Coffea arabica L.) in coffee trees. Can. J. Bot. 76: 542-546.

Cros, J., Combes, M. C., Trouslot, P., Anthony, F., Hamon, F., Charrier, A. and Lashermes, P. 1998. Phylogenetic analysis of chloroplast DNA variation in Coffea L. Mol. Phyl. Evol. 9: 109-117.

Gerlack, W. L. and Bedbrook, J. R. 1979. Cloning and characterization of ribosomal RNA genes from wheat and barley. Nucleic Acids Res. 7: 1869-1885.

Gupta, V., Jagannathan, V. and Lakshmikuraman, M. S. 1990. A novel AT-rich tandem repeat in Brassica nigra. Plant Sci. 68: $223-229$.

Heslop-Harrison, J. S. 1991. The molecular cytogenetics of plants. J. Cell Sci. 100: 15-21.

—, Schwarzacher, T., Anamthawat-Jónsson, K., Leitch, A. R., Shi, M. and Leitch, I. J. 1991. In situ hybridization with automated chromosome denaturation. Technique 3: 109-115.

Lashermes, P., Combes, M. C., Trouslot, P. and Charrier, A. 1997. Phylogenetic relationships of coffee-tree species (Coffea L.) as inferred from ITS sequences of nuclear ribosomal DNA. Theor. Appl. Genet. 94: 947-955.

—, Trouslot, P., Athony, F., Combes, M. C. and Charrier, A. 1996. Genetic diversity for RAPD markers between cultivated and wild accessions of Coffea arabica. Euphytica 87: 59-64.

Lombello, R. A. and Pinto-Maglio, C. A. F. 2002. Heterocromatina e sítios de DNAr de 4 especies de Coffea L. evidenciados por CMA/DAPI et FISH. $48^{\circ}$ Congresso Nacional de Genética, Brasil.

— and - 2003. Estudos citogenéticos em Coffea L. e Psilanthus Hook.f. com o uso de CMA/DAPI et FISH. III. Simpósio de Pesquisas do Café no Brasil, p. 96.

Mangenot, S. and Mangenot, G. 1958. Deuxième liste de nombres chromosomiques nouveaux chez diverses Dicotylédones et Monocotylédones d'Afrique occidentale. Bull. Jard. Bot. Natl. Belgique 28: 315-329.

— and - 1962. Enquête sur les nombres chromosomiques dans une collection d'espèces tropicales. Rev. Cytol. Biol. Vég. 25: 411-447.

Pendas, A. M., Morán, P. and Garcia-Vázquez, E. 1993. Ribosomal genes are interspersed throughout a heterochromatic arm in Atlantic salmon. Cytogenet. Cell Genet. 63: 128-130.

Pierozzi, N. I., Pinto-Maglio, C. A. F. and Cruz, N. D. 1999. Characterization of somatic chromosomes of two diploid species of Coffea L. with acetic orcein and C-band techniques. Caryologia 52: 1-8.

Pinto-Maglio, C. A. F., Cuéllar, T. and Barbosa, R. L. 2000. Aplicação de técnicas de citogenética na caracterização dos cromossomos da espécie Coffea arabica L. I. Simpósio de Pesquisa dos Cafés do Brasil, pp. 444-446.

Raina, S. N., Mukai, Y., Kawaguchi, K. and Goel, S. 2001. Physical mapping of 18S-5.8S-26S and 5S RNA gene families in three imporant vetches (Vicia species) and their allied taxa constituting three species complexes. Theor. Appl. Genet. 103: 830-845.

Schweizer, D. 1976. Reverse fluorescent chromosome banding with Cromomicin and DAPI. Chromosoma 58: $307-354$.

Wrigley, G. 1988. Coffee. Longman Scientific and Technical, John Wiley \& Sons Inc., New York.

Yen-Yu, K., Song-Bin, C., Tsai-Yum, L., Chang-Huain, H., Yao-Huang, C., Wen-Huei, C. and Chi-Chang, C. 2001. Differential accumulation of Heterochromatin as a cause for karyotype variation in Phalaenopsis orchids. Ann. Bot. 87: 387-395. 